27.1 (2020): 1-3

https://doi.org/10.15664/tis.v27i2.2135

\title{
Editorial
}

Two major themes are present in the four papers in this issue of Theology in Scotland - the Church and Creation.

\section{The Church}

In "Theological reflection as a leadership development practice for the post-Christendom Scottish church: Developing moral convictions and navigating new identities", Lal Dhillon discusses the role of theological reflection in church leadership development, with a particular focus on missional leadership in a post-Christendom context. The church faces real challenges in grappling with current concerns and articulating a theological response. Part of the difficulty is that much of this reflection often assumes the Christendom paradigm as normative. Deeper reflection would begin the difficult task of thinking outside this relationship. The church now finds itself situated in multiple contexts which require a range of different responses, among them: the development of leadership, the empowering of young leaders, and a recognition of the importance of transformational leadership. As the church faces the present challenges, theological reflection has the potential to develop leaders in their apostolic task, enable them to cope with 'existing hegemonies of power within the church' and, at the same time, equip them to be responsive to new situations.

In "Presbyterians and conscience", Eric McKimmon explores the nature and role of conscience. The apostle Paul's definition of conscience as an independent witness within the soul enlightened by the Holy Spirit is important here. There is, of course, a wide range of views within historical discussion of the role of conscience. The role of conscience is given a prominent place in the Westminster Confession, which states in Chapter 20 that 'God alone is Lord of the conscience'. Later, Henry Calderwood would give a definition of conscience as 'an authoritative voice within the soul - the representative of divine authority'. The theologian John Oman, advocating a move from an emphasis on doctrinal orthodoxy to a more personal appropriation of faith, affirmed the value of the person and argued that conscience is shaped by experience. 


\section{Editorial}

McKimmon sets out an account of the doctrine of the Holy Spirit in relation to conscience arguing that, with regard to present debates, Presbyterianism needs to reflect more deeply on the renewing power of the Spirit of Christ. This, in turn, raises the question of the further development of mutual respect and understanding in the relationship between the Church of Scotland and the Presbyterian Church in Ireland in the light of the call of the Church to be a Christ-like community in which the conscience of the least of Christ's people remains important.

\section{Creation}

In "The boundless riches of God", David D. Scott explores the concept of infinity. In the Pauline epistles the infinite character of God is recognised in all its fullness. Infinity also emerges as a theological term in the Scots Confession and the Westminster Confession of Faith. The emphasis in this paper, however, is on infinity in mathematics and its relation to theological considerations. Recent writers have reflected on this nexus. John Polkinghorne has described the relation of mathematics to the physical universe as 'a deeper mystery' and Alain Badiou has pointed to the astonishing relation of present mathematical theory to ontology itself. Scott offers a brief account of Euclid, Cantor, and Gödel on the statements of elementary arithmetic and gives an account of Euclid's parallel postulate in relation to Riemann's elliptical geometry, later developed by Einstein in his Theory of Relativity. These mathematical discoveries have implications for (i) the relation of the finite and infinite (which has theological implications for the incarnation); (ii) the relation of theory and reality; (iii) the future scope of discovery and invention; and (iv) further reflection on the givenness of revelation. To conclude with a quote from the paper, 'Whether by analogy or by natural theology, an exploration of mathematical infinity sharpens our perceptions [...] takes us to a place of new horizons and deepens our sense of wonder in the God who has created a universe which can only ultimately be understood in a mathematical way'.

In "Creation and the philosophy of science: Freedom, contingence and the modality of the natural sciences", Alexander Irving explores the relation of the natural world to the triune God and the person of Jesus Christ. The intelligibility of the natural world is not self-derived, and this has implications for the natural sciences. Among other things, the paper 


\section{Editorial}

examines three areas: the nature of reason, the character of theories, and the relation of discursive reason to the ontic order of reality. As part of this examination, Irving examines the doctrine of the Trinity using Aquinas' doctrine of mixed relations, seeking 'an account of divine perfection which preserves both the freedom of God from creation and the freedom of God to be for creation'. With regard to the relation of Christ and creation, the structure of the hypostatic union is established as normative for thought. This, in turn, involves the fundamental concepts of anhypostasia and enhypostasia - normative for an understanding of the complex relation of dependence and independence within a contingent creation. The divinely ordered coherence of creation, then, renders it intelligible to human thought, both the truth in se and pro nobis. A theological account of the natural world is, then, significant. As an account, this is related to the question of the nature and character of theories, in that theories have an ontic correlate. As Irving puts it, 'The natural universe is not a closed system [and] does not have its rationale or order within itself but is open $[\ldots]$ to its source, which is the creative wisdom of God'.

Review essay

In addition to these papers, Jonathan Birch, our new Reviews Editor, contributes an essay-length review of David Bentley Hart's recent book That All Shall Be Saved: Heaven, Hell, and Universal Salvation.

Ian Maxwell Editor 